\title{
Toxicity and Disruptive Impacts of Novaluron, A Chitin Synthesis Inhibitor, on Development and Metamorphosis of The Olive Leaf Moth Palpita unionalis (Hübner) (Lepidoptera: Pyralidae)
}

\author{
${ }^{1}$ K. Ghoneim, ${ }^{2}$ Kh. Hamadah, ${ }^{3}$ A. N. Mansour, ${ }^{4}$ A. A. Abo Elsoud \\ 1,2,4 Department of Zoology and Entomology, Faculty of Science, Al-Azhar University, Cairo, Egypt \\ ${ }^{3}$ Desert Research Center, Cairo, Egypt \\ *Corresponding author: karemghoneim@gmail.com
}

\section{ABSTRACT}

The olive leaf moth Palpita unionalis (Lepidoptera: Pyralidae) is an economic pest of the commercial olive groves in Egypt and different Mediterranean countries. The present study was conducted aiming to assess the effects of Novaluron, a chitin synthesis inhibitor, on survival, growth, development and metamorphosis of this pest. The newly moulted last instar (6th) larvae had been treated with six concentrations $(100.0,10.0,1.00,0.10,0.01$ and $0.001 \mathrm{ppm})$, via the fresh olive leaves, as food. Different degrees of toxicity were recorded on all developmental stages. LC $_{50}$ was calculated in 0.97 ppm. The somatic weight gain of larvae was drastically reduced and the larval growth rate was severely regressed, regardless the concentration. The larval duration was generally shortened but the pupal duration was remarkably prolonged, in a dosedependent manner. The pupation rate was regressed, especially at the higher four concentrations. The metamorphosis program was impaired, since larvalpupal intermediates had been produced at some concentrations. In addition, the pupal morphogenesis was disrupted, since some pupal deformities had been observed at some concentrations.

Keywords: growth, larva, morphogenesis, mortality, pupa, toxicity

\section{INTRODUCTION}

From the Zoogeographical point of view, the Mediterranean Basin was reported as the original area of the olive leaf moth Palpita unionalis (Hübner)(Lepidoptera: Pyralidae). Now it is an international lepidopterous migratory pest in the tropical and subtropical regions of the Old World [1, 2]. P. unionalis is one of the most dangerous pests of olives in Egypt and other Mediterranean countries [36]. The most important damage of this pest occurs on young trees, nurseries and shoots of old trees [7, 8]. The control of $P$. unionalis on olive trees has relied upon the use of traditional synthetic insecticides [9]. Different pesticides exhibited a good control when applied on the early larval instars [10]. Insecticide residues have been detected in olive oil and in the environment where olives are grown [11]. In addition, the extensive use of conventional insecticides has caused resistant insect strains to emerge $[12,13]$ and serious toxicological problems to humans and the environment $[14,15]$. Therefore, alternative materials have been initiated recently to minimize the pesticide hazards and introduce of new effective and safer ways and negligible effects on ecosystem.

Over the past four decades, efforts have been made to develop insecticidal compounds with selective properties that act specifically on biochemical sites that are present in particular insect groups but with properties that differ from conventional insecticides[16-18]. Insect Growth Regulators (IGRs) belong to a group of compounds which are not directly toxic, but act selectively on normal growth, development metamorphosis and/or reproduction in insects via disrupting the hormonally regulated physiological processes [19-24]. Because of their desirable characteristics, such as low toxicity, less environmental pollution, high selectivity, and low impact on natural enemies and people, IGRs are used to control various insect pests [25-27]. Several IGRs have been extensively studied for investigating their effects on metamorphosis and reproduction in a number of insect species [28, 29]. On the basis of the mode of action, IGRs had been grouped in three categories: (i) Juvenile hormone analogues (JHAs) (also called as Juvenoids), (ii) Ecdysteroid agonists and (iii) Chitin synthesis inhibitors (CSIs) or moult 
inhibitors [30, 16, 31]. They had been, also, grouped in CSIs and substances that interfere with the action of insect hormones (i.e. juvenile hormone analogues, and ecdysteroids) [32].

CSIs interfere with chitin biosynthesis in insects and thus prevent moulting, or produce an imperfect cuticle [33]. By affecting the hormonal balance, they disrupt several physiological processes in insect body [33]. Also, CSIs are less toxic compounds to the non-target organisms and beneficial biota and have no residual effects [34]. One of the novel benzoylphenyl ureas is the Novaluron. It inhibits the chitin formation on larvae of various insects of different orders $[35,36]$ and exhibits a high toxicity against several dipterous species [37-42]. It is, also, a powerful suppressor of lepidopteran larvae [43] and whiteflies [44, 45] as well as some species of Hemiptera $[46,47]$ and Coleoptera [48-50]. The disruptive effects of Novaluron on survival, growth, development, metamorphosis and/or morphogenesis had been reported in some insects, such as Helicoverpa armigera [51], Musca domestica [37], Phlebotomus papatasi [38], Aedes aegypti [52, 39, 53], Culex pipiens [42], Stomoxys calcitrans [54] and Spodoptera littoralis [55], Pectinophora gossypiella [56] as well as it disrupted the adult performance and reproductive potential [57], declined the main metabolites [58], and deteriorated the larval haemogram [59] of the latter lepidopteran pest. Its residues tend to dissipate with half-life of 2.08 days and the safe use of it on tomatoes, and possibly on other crops in Egypt was established [60]. The compound has no appreciable effect on natural enemies [44] and low mammalian toxicity $[61,62]$. Depending on the currently available literature, no body assessed the effects of Novaluron on $P$. unionalis. Taking all of these considerations into account, the present study was carried out aiming to investigate the effects of Novaluron on the survival, growth, development, metamorphosis of this serious pest.

\section{MATERIALS AND METHODS}

\section{Experimental insect.}

A sample of olive leaf moth Palpita unionalis (Hubner) (Lepidoptera: Pyralidae) larvae was kindly obtained from the culture of susceptible strain maintained for several generations in Desert Research Center, Cairo, Egypt. A new culture was maintained in Department of Zoology and Entomology, Faculty of Science, Al-Azhar University, Cairo, Egypt, under laboratory controlled conditions $\left(27 \pm 2^{\circ} \mathrm{C}, 65 \pm 5 \%\right.$ R.H., photoperiod 14 and $10 \mathrm{~h} \mathrm{L:D)} \mathrm{according} \mathrm{to}$ Mansour [63]. Larvae were daily provided with fresh olive leaves Olea europaea L, as a food. After the larval stage, the developed pupae were collected and transferred to Petri dishes $(5.5 \times 1.4 \mathrm{~cm})$. The emerged adults were daily collected and released in plastic jars (3L) provided with cotton pieces, soaked in $10 \%$ sugar solution, for feeding, as well as olive twigs ( 20 $\mathrm{cm}$ in length) as an oviposition site. After egg deposition, adult males and females were transferred into new plastic jars. The jars of eggs were provided with fresh tender olive twigs fixed in a small bottle containing water, so as to keep the leaves flat and fresh, for feeding of the newly hatched larvae. The fresh tender olive leaves were renewed daily until pupation.

\section{Bioassay of Novaluron.}

Novaluron [1-[chloro-4-(1,1,2trifluoromethoxyethoxy) phenyl] -3- (2,6difluorobenzoyl) urea] has the molecular formula: $\mathrm{C}_{17} \mathrm{H}_{9} \mathrm{ClF}_{8} \mathrm{~N}_{2} \mathrm{O}_{4}$. It was supplied by Sigma-Aldrich Chemicals. A series of concentration levels of Novaluron was prepared by diluting with distilled water in volumetric flasks as follows: 100.0, 10.0, 1.0, $0.1,0.01$ and $0.001 \mathrm{ppm}$. Bioassay tests were carried out using the newly moulted last instar $\left(6^{\text {th }}\right)$ larvae. Fresh olive leaves were dipped in each concentration of Novaluron for 5 minutes and air dried before introduction to larvae for feeding. Control larvae were provided with water-treated olive leaves. Ten replicates of treated and control larvae (one larva/replicate) were kept separately in glass vials. The larvae were allowed to feed on treated leaves for $24 \mathrm{hrs}$. Then, they provided with fresh untreated olive leaves and all biological and physiological parameters were recorded daily. 


\section{Criteria of study.}

\subsection{Toxicity test.}

All mortalities of treated and control (larvae, pupae and adults) were recorded every day and corrected according to Abbott's formula [64] as follows:

$\%$ of test mortality - $\%$ of control mortality

$\%$ of corrected mortality X100

\section{$100-\%$ of control mortality}

The $\mathrm{LC}_{\mathbf{5 0}}$ value was calculated for general mortality by Microsoft office Excel, 2007, according to Finney [65].

\subsection{Growth, development and metamorphosis.}

Weight gain: Each individual larva (treated and control) was carefully weighed every day using a digital balance for calculating the growth as follows:

Initial weight (before the beginning of experiment) final weight (at the end of experiment).

Growth rate: Growth rate (GR) can be calculated according to Waldbauer [66] as follows:

$\mathrm{GR}=$ fresh weight gain during feeding period / feeding period $\mathrm{X}$ mean fresh body weight of larvae during the feeding period.

Developmental rate: Dempster's equation [67] was applied for calculating the developmental duration, and Richard's equation [68] was used for calculating the developmental rate.

Pupation rate: The pupation rate was expressed in \% of the successfully developed pupae.

Deranged metamorphosis: different features of impaired metamorphosis program of $P$. unionalis were observed as larval-pupal intermediates, pupaladult intermediates or extra moult and calculated in (\%). Also, impaired pupal morphogenesis was observed as pupal deformations and calculated in $\%$.
Various features of impaired metamorphosis and morphogenesis were recorded in photos.

\subsection{Pupal water loss.}

Pupal water loss was calculated depending on the data of the initial and final weights of the pupae, as follows:

Water loss $\%=[$ initial weight - final weight /initial

$$
\text { Weight }] \times 100
$$

\section{Statistical analysis of data.}

Data obtained were analyzed by the Student's $t$ distribution, and refined by Bessel correction [69] for the test significance of difference between means.

\section{RESULTS}

\section{Toxicity and lethal effects.}

After treatment of the newly moulted last instar (6th) larvae of $P$. unionalis with six concentrations of Novaluron $(100.0,10.0,1.00,0.10,0.01$ and 0.001 $\mathrm{ppm}$ ), via the fresh olive leaves, as food, data of toxicity and lethal effect on all developmental stages were distributed in Table (1). Depending on these data, Novaluron failed to affect the larval survival at the lower two concentrations but it exhibited various degrees of toxicity on larvae, at other concentrations, in no certain trend. The successfully developed pupae suffered a toxic effect of the tested compound, since different mortality \%s had been recorded, in a dosedependent course $(20.0,20.0,28.5,40.0,71.4$ and $100 \%$ mortality, at $0.001,0.01,0.10,1.00,10.00$ and $100 \mathrm{ppm}$, respectively). As clearly shown, complete pupal mortality was recorded at the highest concentration of Novaluron. With regard to the adult moths, Novaluron failed to affect their survival except $0.01 \mathrm{ppm}$ at which $12.5 \%$ adult mortality was estimated. The corrected mortality was found in a dose-dependent manner (for detail, see Table 1). $\mathrm{LC}_{50}$ was calculated in 0.97 ppm. 


\section{www.ijtsrd.com}

\section{Effects on Growth, Development Metamorphosis.}

The most important growth, developmental and metamorphic criteria of $P$. unionalis, after treatment of newly moulted last instar larvae with six concentration levels of Novaluron, were summarized in Table (2). According to these data, the somatic weight gain of larvae was drastically reduced, in a dose- dependent course $(2.44 \pm 3.18,2.42 \pm 1.45$, $2.27 \pm 0.50,2.10 \pm 1.46,1.84 \pm 1.48$ and $1.42 \pm 0.63 \mathrm{mg}$, at $0.001,0.01,0.10,1.00,10.0$ and $100 \mathrm{ppm}$, respectively, in comparison with $6.23 \pm 3.34 \mathrm{mg}$ of control larvae). Also, Novaluron exhibited a strong suppressing effect on the larval growth rate, regardless the concentration $(0.017 \pm 0.004$, $0.019 \pm 0.002, \quad 0.019 \pm 0.002, \quad 0.013 \pm 0.006$, $0.015 \pm 0.001,0.014 \pm 0.001$, at $100,10.0,1.00,0.10$, 0.01 and $0.001 \mathrm{ppm}$, respectively, vs. $0.034 \pm 0.007$ of control larvae). In addition, the larval duration was generally shortened, in a dose-dependent course $(3.33 \pm 0.50, \quad 3.30 \pm 0.48, \quad 3.28 \pm 0.48, \quad 2.20 \pm 0.44$, $2.14 \pm 0.37$ and $1.75 \pm 0.50$ days, at $0.001,0.01,0.10$, $1.00,10.00$ and $100 \mathrm{ppm}$, respectively, vs. $3.60 \pm 0.69$ days of control larvae). Developmental rate of larvae is another parameter indicating an enhancing action of Novaluron, since the treated larvae developed in faster rate than control congeners. As obviously shown in the previously mentioned table, a reversal action of Novaluron was exerted on the developed pupae, since their duration was remarkably prolonged, in a dosedependent manner $(9.25 \pm 1.98,9.28 \pm 0.75,9.60 \pm 0.54$, $10.66 \pm 1.52$ and $12.50 \pm 0.70$ days, at $0.001,0.01,0.10$, 1.00 and 10.0 ppm, respectively, vs. $9.20 \pm 0.78$ days of control pupae). This prolongation of pupal stage was reflected in a retarded development, i.e., pupae developed in slower rate than that of control pupae (for detail, see Table 2).

Because the pupal death may be due to the desiccation caused by Novaluron, loss of body water was estimated in \%. In general, the successfully developed pupae from treated larvae lost more body water than control pupae $(28.6,31.0,31.0,31.0$ and $38.7 \%$, at $0.001,0.01,0.10,1.0$ and $10.0 \mathrm{ppm}$, respectively, compared to $28.2 \%$ of control pupae).

With regard to the effects of Novaluron on metamorphosis and morphogenesis of P. unionalis, data listed in Table (2) exiguously revealed various disruptive effects such as the regressed pupation rate, especially at the higher four concentrations (70, 60, 80 and $40 \%$, at $0.10,1.0,10.0$ and $100 \mathrm{ppm}$, respectively, vs. $100 \%$ pupation on control larvae). The metamorphosis program was impaired, since larvalpupal intermediates had been produced at some concentration levels $(10,30$ and $10 \%$ at $0.10,1.00$ and $10.0 \mathrm{ppm}$, respectively). Description of these intermediate creatures was provided in Plate (1). Moreover, $10 \%$ of pupal-adult intermediates had been produced only at $0.01 \mathrm{ppm}$ (see Plate 2 ). In addition, the pupal morphogenesis was disrupted, since some pupal deformities had been observed at some concentration levels (12.5 and $20.0 \%$, at 10.0 and 1.0 ppm, respectively). Some malformed pupae had been observed in non-tanned segmented body or segmented body with tanned part and incompletely tanned part, depending on the concentration level of Novaluron (see Plate 3). 
International Journal of Trend in Scientific Research and Development, Volume 1(4), ISSN: 2456-6470 www.ijtsrd.com

Table 1 . Toxicity and lethal effects (\%) of Novaluron treatment of newly moulted last instar larvae of $P$. unionalis.

\begin{tabular}{|c|c|c|c|c|c|c|}
\hline $\begin{array}{c}\text { Conc. } \\
\text { (ppm) }\end{array}$ & $\begin{array}{c}\text { Larval } \\
\text { mortality }\end{array}$ & $\begin{array}{c}\text { Pupal } \\
\text { mortality }\end{array}$ & $\begin{array}{c}\text { Adult } \\
\text { mortality }\end{array}$ & $\begin{array}{c}\text { Total } \\
\text { mortality }\end{array}$ & $\begin{array}{c}\text { Corrected } \\
\text { mortality }\end{array}$ & \multirow{2}{*}{ LC $_{\mathbf{5 0}}$} \\
\hline $\mathbf{1 0 0}$ & 60 & 100 & $*$ & 100 & 100 & \\
\hline $\mathbf{1 0 . 0}$ & 30 & 71.4 & 00.0 & 80 & 80 \\
\hline $\mathbf{1 . 0 0}$ & 50 & 40.0 & 00.0 & 70 & 70 & \multirow{2}{*}{0.97} \\
\cline { 1 - 5 } $\mathbf{0 . 1 0}$ & 30 & 28.5 & 00.0 & 50 & 50 & \\
\cline { 1 - 5 } $\mathbf{0 . 0 1}$ & 00 & 20.0 & 12.5 & 30 & 30 & \\
\hline $\mathbf{0 . 0 0 1}$ & 00 & 20.0 & 00.0 & 20 & 20 & \\
\hline Control & 00 & 00.0 & 00.0 & 0 & --- & \\
\hline
\end{tabular}

Conc.: Concentration level. *: no adults.

Table 2. Growth and developmental effects of Novaluron treatment of newly moulted last instar larvae of P. unionalis.

\begin{tabular}{|c|c|c|c|c|c|c|c|c|c|c|c|}
\hline \multirow[b]{2}{*}{$\begin{array}{l}\text { Conc. } \\
\text { (ppm) }\end{array}$} & \multicolumn{5}{|c|}{ Larval stage } & \multicolumn{6}{|c|}{ Pupal stage } \\
\hline & $\begin{array}{c}\text { Weight } \\
\text { gain } \\
(\mathrm{mg} \pm \mathrm{SD})\end{array}$ & $\begin{array}{l}\text { Growth rate } \\
(\text { Mean } \pm \text { SD) }\end{array}$ & $\begin{array}{c}\text { Larval } \\
\text { duration } \\
\text { (Mean } \\
\text { days } \pm \text { SD) }\end{array}$ & $\begin{array}{l}\text { Devel } \\
\text { op. } \\
\text { rate }\end{array}$ & $\begin{array}{c}\text { Larv } \\
\text { al- } \\
\text { pupal } \\
\text { inter. } \\
(\%)\end{array}$ & $\begin{array}{c}\text { Pupa } \\
\text { tion } \\
(\%)\end{array}$ & $\begin{array}{c}\text { Pupal } \\
\text { duration } \\
\text { (Mean } \\
\text { days } \pm \text { SD) }\end{array}$ & $\begin{array}{l}\text { Devel } \\
\text { op. } \\
\text { rate }\end{array}$ & $\begin{array}{c}\text { Pupal } \\
- \\
\text { adult } \\
\text { inter. } \\
(\%)\end{array}$ & $\begin{array}{c}\text { Pupal } \\
\text { defor } \\
\text { mities } \\
(\%)\end{array}$ & $\begin{array}{l}\text { Wat } \\
\text { er } \\
\text { loss } \\
(\%)\end{array}$ \\
\hline 100 & $1.42 \pm 0.63 \mathrm{~b}$ & $0.017 \pm 0.004 \mathrm{~d}$ & $1.75 \pm 0.50 \mathrm{~d}$ & 57.1 & 00 & 40 & $*$ & $*$ & $*$ & $*$ & --- \\
\hline 10.0 & $1.84 \pm 1.48 \mathrm{~b}$ & $0.019 \pm 0.002 \mathrm{~d}$ & $2.14 \pm 0.37 \mathrm{~d}$ & 46.7 & 10 & 80 & $12.50 \pm 0.70 \mathrm{~d}$ & 8.00 & 00 & 12.5 & 38.7 \\
\hline 1.00 & $2.10 \pm 1.46 \mathrm{~b}$ & $0.019 \pm 0.002 \mathrm{~d}$ & $2.20 \pm 0.44 \mathrm{c}$ & 45.4 & 30 & 60 & $10.66 \pm 1.52 \mathrm{~b}$ & 9.38 & 00 & 20.0 & 31.0 \\
\hline 0.10 & $2.27 \pm 0.50 \mathrm{c}$ & $0.013 \pm 0.006 \mathrm{~d}$ & $3.28 \pm 0.48 \mathrm{a}$ & 30.4 & 10 & 70 & $9.60 \pm 0.54 \mathrm{a}$ & 10.4 & 00 & 00.0 & 31.0 \\
\hline 0.010 & $2.42 \pm 1.45 \mathrm{c}$ & $0.015 \pm 0.001 \mathrm{~d}$ & $3.30 \pm 0.48 \mathrm{a}$ & 30.3 & 00 & 100 & $9.28 \pm 0.75 \mathrm{a}$ & 10.7 & 10 & 00.0 & 31.0 \\
\hline 0.001 & $2.44 \pm 3.18 \mathrm{~b}$ & $0.014 \pm 0.001 \mathrm{~d}$ & $3.33 \pm 0.50 \mathrm{a}$ & 30.0 & 00 & 100 & $9.25 \pm 1.98 \mathrm{a}$ & 10.7 & 00 & 00.0 & 28.6 \\
\hline Control & $6.23 \pm 3.34$ & $0.034 \pm 0.007$ & $3.60 \pm 0.69$ & 27.7 & 00 & 100 & $9.20 \pm 0.78$ & 10.8 & 00 & 00.0 & 28.2 \\
\hline
\end{tabular}

Conc.: See footnote of Table (1). Develop. rate: Developmental rate. inter.: intermediates. Mean \pm SD followed with the letter (a): not significantly different ( $p>0.05)$, (b): significantly different $(p<0.05)$, (c): highly significantly different $(p<$ $0.01)$, (d): very highly significantly different $(\mathrm{p}<0.001)$. * died pupae. 


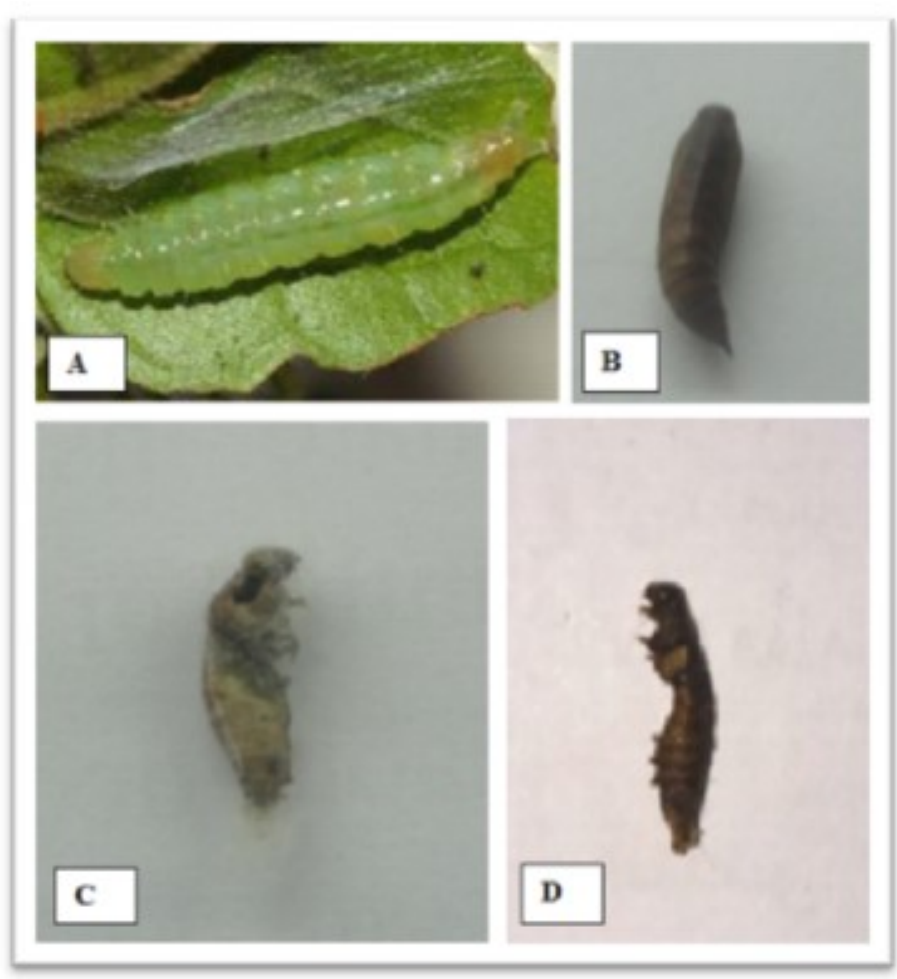

Plate 1. Larval-pupal intermediates of $P$. unionalis as a feature of disturbed metamorphosis program after treatment of newly moulted last instar larvae with Novaluron. (A): Control larva. (B): Control pupa. (C): Larval-pupal intermediate (larval head and thorax with pupal abdomen: $10.0 \mathrm{ppm}$ and $1.0 \mathrm{ppm}$ ). (D): Larval-pupal intermediate (pupated dorsal part with larval legs and head: $0.1 \mathrm{ppm}$ and $1.0 \mathrm{ppm}$ ).

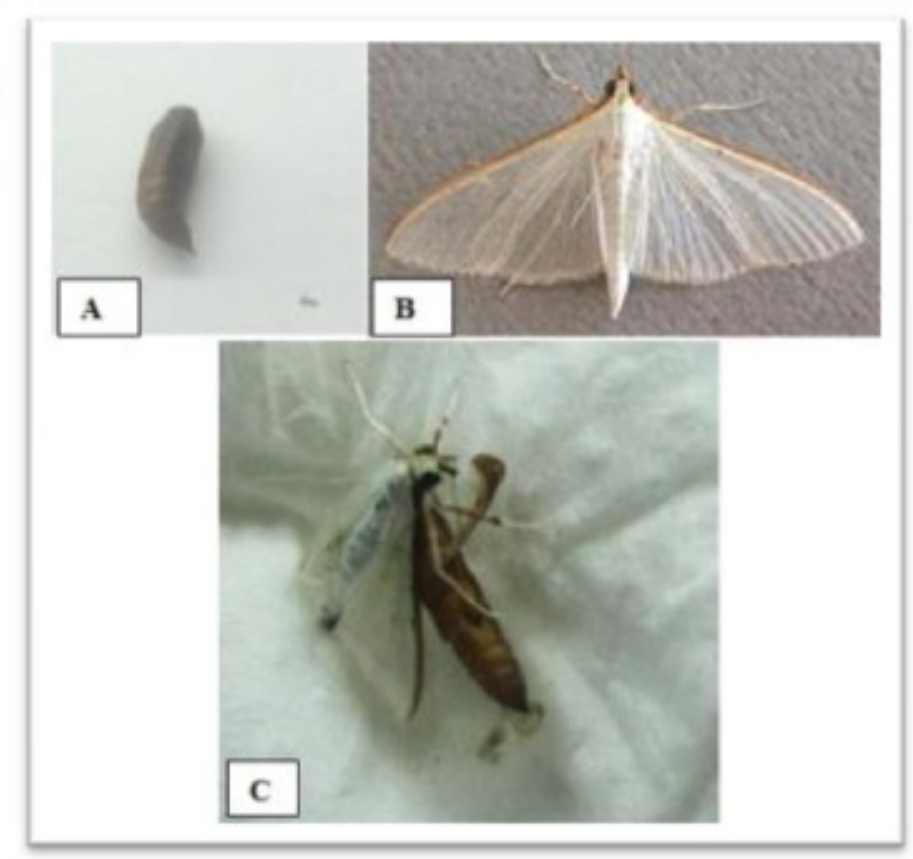

Plate 2. Pupal-adult intermediate of $P$. unionalis as a feature of disturbed metamorphosis program after treatment of newly moulted last instar larvae with Novaluron. (A): Control pupa. (B): Control adult. (C): Pupal-adult intermediate (0.01 ppm).

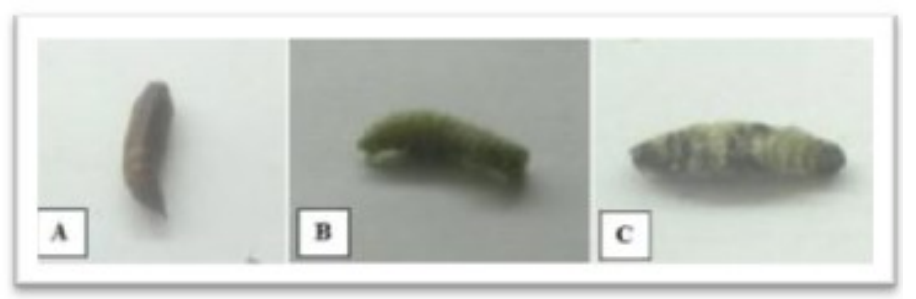

Plate 3. Deteriorated pupal morphogenesis of $P$. unionalis by Novaluron. (A) Control pupa (B): deformed pupa: non-tanned segmented body (1ppm). (C): deformed pupa: segmented pupa with tanned part and incompletely tanned part (10 ppm).

\section{DISCUSSION}

\section{Affected survival potential of $P$. unionalis by Novaluron.}

The currently available literature contains many reported results of toxic effects of several insect growth regulators (IGRs)(Juvenoids, ecdysteroids and chitin synthesis inhibitors, CSIs) on various insect species, such as Spodoptera littoralis by Diflubenzuron [70], Triflumuron [71], Flufenoxuron [72], Lufenuron [73,74], Buprofezin [75,76], Tebufenozide and Methoxyfenozide [77], Cyromazine [78]; Papilio demoleus by Diofenolan [79]; Eurygaster integriceps by Pyriproxyfen [80]; Dysdercus koenigii by Flufenoxuron [81]; Halyomorpha halys by Diflubenzuron [46]; Spodoptera litura by Chlorfluazuron [82]; Locusta migratoria var. manilensis by Flufenoxuron, RH-5849 and Pyriproxyfen [83]; Culex pipiens by Kinoprene [84]; Agrotis ipsilon by Flufenoxuron and Methoprene [85] or Pyriproxyfen [86] and Tribolium castaneum by Lufenuron [87]. Recently, IGRs of different categories exhibited varying degrees of toxicity against some insects, such as Pyriproxyfen against Spodoptera mauritia [29]; Lufenuron and Methoxyfenozide against T. castaneum [88]; 
Methoxyfenozide against C. pipiens [89]; RH-5849 and Tebufenozide (RH-5992) against Ephestia kuehniella [90]; Lufenuron against Glyphodes pyloalis [91] and Helicoverpa armigera [92]; Fenoxycarb against Corcyra cephalonica [93,94]; Buprofezin against Paracoccus marginatus [95]; Chlorfluazuron, Cyromazine, Lufenuron, and Precocene I against Ctenocephalides felis [96]; Methoprene and Pyriproxyfen against Culex quinquefasciatus and Aedes albopictus [97]; Cyromazine against Musca domestica, Stomoxys calcitrans and Fannia canicularis [98], as well as Pyriproxyfen and Methoxyfenozide [99] and Novaluron [56] against Pectinophora gossypiella.

Results of the present study on $P$. unionalis were, to some extent, in agreement with the previously reported results of toxicity, since Novaluron (a chitin synthesis inhibitor, CSI) exhibited various degrees of toxicity on larvae, at all concentrations, except the lower two concentrations. Also, different pupal mortality \%s had been recorded, in a dose-dependent course. Only at $0.01 \mathrm{ppm}$ of Novaluron, $12.5 \%$ of adult mortality was estimated.

As reported in the available literature, $\mathrm{LC}_{\mathbf{5 0}}$ values of Novaluron and lufenuron against $S$. litura were determined as 350.45 and $453.78 \mathrm{ppm}$, respectively [100]; $\mathrm{LC}_{\mathbf{5 0}}$ of Pyriproxyfen was found to be $0.025 \%$ against $S$. litura larvae [86]; LC $_{\mathbf{5 0}}$ of Hexaflumuron against $H$. armigera was $8.47 \mathrm{mg} / \mathrm{L}$ [101]; LD $_{\mathbf{5 0}}$ values of RH-5849 and Tebufenozide against $E$. kuehniella were 0.05 and $0.005 \mu \mathrm{g} /$ insect, respectively[90]; $\mathrm{LC}_{\mathbf{5 0}}$ of Methoxyfenozide against Culex pipiens was calculated in $24.54 \mu \mathrm{g} / \mathrm{L}$ [89]; $\mathrm{LC}_{\mathbf{5 0}}$ of Lufenuron against $G$. pyloalis was 19 ppm [91] and $\mathrm{LC}_{\mathbf{5 0}}$ values of Chlorfluazuron, Cyromazine, Lufenuron and Precocene I against C. felis were 0.19, 2.66, 0.20, and 10.97 ppm, respectively [96]. Also, a variation in $\mathrm{LC}_{\mathbf{5 0}}$ values was reported for Novaluron on $S$. littoralis, since $\mathrm{LC}_{\mathbf{5 0}}$ values were 2.71 and 2.65 ppm, after treatment of penultimate instar larvae and last instar larvae, respectively [55]. In the current investigation on P. unionalis, $\mathrm{LC}_{\mathbf{5 0}}$ of Novaluron was calculated in $0.97 \mathrm{ppm}$. Thus, $\mathrm{LC}_{\mathbf{5 0}}$ value depends on several factors, such as susceptibility of the insect and its treated stage or instar, lethal potency of the tested compound and its concentration levels, method and time of treatment, as well as the experimental conditions.

To explicate the recorded toxic effect of Novaluron on larvae, pupae and adults of $P$. unionalis, in the present study, IGRs exhibit their toxic effects on insects with a mode of action other than that of conventional insecticides. Furthermore, CSIs interfere with the synthesis and/or deposition of chitin on the exoskeleton or other chitinized internal structures, such as the peritrophic matrix, hindering the role of peritrophic membrane in protecting the secreting cells from damage [102,103]. Furthermore, it was suggested that the tested CSI interferes with the transport system of UDP-N-acetyl amine across the membrane [104].

For some detail, the larval deaths of $P$. unionalis by Novaluron, in the current study, may be attributed to the failure of larvae to moult (lethal moult) owing to the inhibition of chitin formation $[105,106]$, to the inability to shed their exocuticle [107], or to swallow volumes of air for splitting the old cuticle and expand the new one during ecdysis [108]. Also, these larval deaths may be due to the prevented feeding and continuous starvation of the present insect [109].

Although the disturbance of hormonal regulation or the disrupting of normal activity of the endocrine system in insects by IGRs was reported $[110,111]$ and suggested for some mosquito species [35,112], the pupal deaths in $P$. unionalis, in the present investigation, could not be directly relate to the hormonal activity of Novaluron, but to other causes, such as suffocation, bleeding and desiccation due to imperfect exuvation, failure of vital homeostatic mechanisms, etc. [113]. This suggestion can easily be substantiated since Novaluron exerted a predominant desiccating action on the successfully developed pupae of $P$. unionalis to lose more body water than control pupae, in the present study. 
In addition, the adult mortality of $P$. unionalis after treatment of newly moulted last instar larvae only with $0.01 \mathrm{ppm}$ of Novaluron, in the current study, can be explained by the retention and distribution of this compound in the insect body as a result of rapid transport from the gut of treated larvae into other tissues, by the direct and rapid transport via the haemolymph to other tissues, and/or by lower detoxification capacity of adults against the tested CSI [114].

\section{Disturbance of growth and development of $\boldsymbol{P}$. unionalis by Novaluron.}

Depending on the currently available literature, some authors have taking into account the body weight gain by the insect larvae as a valuable indicator for growth [115]. In the present study, both larval weight gain and growth rate had been determined after treatment of newly moulted last $\left(6^{\text {th }}\right)$ instar larvae of $P$. unionalis with different concentrations of Novaluron. The somatic weight gain of larvae was drastically reduced and the larval growth rate was severely regressed, regardless the concentration. Also, larval duration was generally shortened and the developmental rate of these larvae was enhanced.

However, the inhibited growth of $P$. unionalis by Novaluron, in the present study, was in accordance with those reported results of inhibited growth of some insects by various IGRs, such as Spodoptera littoralis by Tebufenozide [116], Flufenoxuron[71], Lufenuron [106], Triflumuron [72] and Novaluron [117, 55]; Ciratitis capitata by Cyromazine [118], $P$. demoleus by Diofenolan [79], S. litura by Chlorfluazuron [82], Aedes aegypti [53] and Culex pipiens [42,112] by Novaluron, $C$. pipiens by Kinoprene [84] and A. ipsilon by Methoprene and Flufenoxuron [85]. Likewise, some IGRs failed to affect the growth of various insects, such as $M$. domestica [119], Periplaneta americana and Oncopeltus fasciatus [120], Spodoptera exempta, Spodoptera exigua, and Leptinotarsa decemlineata [113].
On the other hand, the present results of shortened larval duration and enhanced developmental rate of $P$. unionalis larvae were in agreement with the reported results of shortened larval duration of $P$. gossypiella after treatment of newly hatched larvae with Methoxyfenozide [99] and other insects, such as Rhynchophorus ferrugineus by Lufenuron and Diofenolan [121], A. ipsilon by Flufenoxuron [122] and Schistocerca gregaria by Lufenuron [123]. On the contrary, the present results disagreed with the reported results of prolonged larval duration of $S$. littoralis larvae after treatment of penultimate or last instar larvae with by Novaluron [55] and Cyromazine [78]; prolonged larval duration after treatment of $5^{\text {th }}$ instar larvae of Spodoptera frugiperda with $\mathrm{LC}_{\mathbf{1 0}}$ and $\mathrm{LC}_{25}$ of Methoxyfenozide [124] and prolonged larval duration in $P$. gossypiella after treatment of the first instar larvae with Pyriproxyfen [99].

Lepidoptera belong to the most sensitive groups of insects regarding the growth regulating effects of IGRs. The inhibited growth of $P$. unionalis by some concentrations of Novaluron, in the current study, may be a result of the blocked release of morphogenic peptides, causing alteration in the ecdysteroid and juvenoid titers [125]. Also, Novaluron may affect the tissues and cells undergoing mitosis[126].

As reported in the available literature, many IGRs (including CSIs) exhibited some inhibitory effects on the general development of various insects, such as $S$. littoralis by Diflubenzuron [70], Methoprene and Fenoxycarb [127], Lufenuron [73], Novaluron [55] and Cyromazine [78]; P. demoleus by Diofenolan [79]; S. litura by Chlorfluazuron [82]; A. aegypti [53] and $C$. pipiens $[42,112]$ by Novaluron; $C$. pipiens by Kinoprene [84]; A. ipsilon by Methoprene and Flufenoxuron [85]; P. gossypiella by Diflubenzuron and Chlorfluazuron [128], Buprofezin [129]; Teflubenzuron [130] and Chromafenozide [131]. Recently, the developmental duration was prolonged indicating retarded development in some other insects by various IGRs, such as G. pyloalis by Lufenuron [91]; C. pipiens by Methoxyfenozide[89] and N-tertbutylphenyl thenoylhydrazide (ecdysteroid derivative) 
[132]; C. cephalonica by Fenoxycarb [94]; $P$. gossypiella by Lufenuron and Pyriproxyfen [99] and Novaluron [56]; etc. In agreement with those reported results of retarded development, the present study recorded a powerful retarding effect of Novaluron on the development of $P$. unionalis, since the pupal duration was remarkably prolonged and the developmental rate of pupae was considerably regressed.

In the current study, retarded development of $P$. unionalis by Novaluron, as expressed in prolonged pupal duration and regressed developmental rate, may be attributed to the indirect interference of this CSI with neuroendocrine organs responsible for the synthesis and release of tropic hormones, like prothoracicotropic hormone (PTTH)[133]. The prolongation of larval or pupal duration may be due to the persistence of juvenile hormone $(\mathrm{JH})$ in the haemolymph where it is only in the absence of JH that ecdysone could be activated and lead to the formation of the next stage [134]. Also, Novaluron may exhibit a delaying effect on the ecdysis and transformation [108]. In particular, the final step of chitin biosynthesis pathway was inhibited by this CSI and the precursor was not converted into chitin leading to a prolongation of developmental duration [112].

\section{Impaired metamorphosis and morphogenesis of $P$. unionalis by Novaluron.}

The effects exhibited by IGRs on insect metamorphosis may be important from the practical stand-point because they could result in various morphogenic defects as well as mortality [135]. Depending on the available literature, the major symptoms and features of the impaired metamorphosis of an insect after treatment with various IGRs (including CSIs) had been described as reduction of pupation and adult emergence, production of larval-pupal and/or pupal-adult intermediates, deformed larvae and/or pupae and the production of supernumerary larval instars (superlarvae). However, all or some of these features were observed in various insects as responses to the disruptive effects of different IGRs, such as $S$. littoralis by Chlorfluazuron [136], Triflumuron [72], Lufenuron [105,106], Flufenoxuron [71,72], Methoprene and Fenoxycarb [127]; Novaluron [55] and Cyromazine [78]. Also, some or all of these symptoms of the impaired metamorphosis were recorded after treatment of different insects with several IGRs, such as $T$. castaneum and $T$. confusum [137], Liriomyza trifolii [138] and Callosobruchus maculates [139] by Cyromazine; H. armigera [51], Phlebotomus papatasi [38], A. aegypti [52, 39], M. domestica [54] by Novaluron; Lipaphis erysimi by Pyriproxyfen [140]; Rh. ferrugineus [121] and $P$. demoleus [79] by Diofenolan; Lobesia botrana by Lufenuron [141]; C. pipiens by Kinoprene [84]; etc.

In the present study on $P$. unionalis, Novaluron detrimentally prohibited the pupation process, since pupation $\%$ considerably decreased, especially at the higher four concentrations. This results was, to a great extent, consistent with those reported results of reduced pupation rate of some insects by various IGRs, such as $P$. xylostella by Hexaflumuron [142], $S$. littoralis by Novaluron [55] and Cyromazine [78], G. pyloalis by Lufenuron [91] and Fenoxycarb [93] as well as Encarsia formosa by Pyriproxyfen and Fenoxycarb [24].

In the present study on $P$. unionalis, the pupal morphogenesis was deranged, since different pupal deformities had been observed, at some concentrations of Novaluron. Some malformed pupae appeared in non-tanned segmented body or segmented body with tanned part and incompletely tanned part, depending on the concentration level of Novaluron. To some extent, similar deranged pupal morphogenesis had been reported for $T$. castaneum and $T$. confusum after treatment with Cyromazine [137], Spodoptera frugiperda after feeding of $5^{\text {th }}$ instar larvae on a diet treated with $\mathrm{LC}_{10}$ and $\mathrm{LC}_{25}$ of Methoxyfenozide [124], C. cephalonica after topical application of last instar larvae with Fenoxycarb [94] and $P$. gossypiella after treatment of the full grown larvae with Novaluron [56]. Whatever the mode of action, Novaluron suppressed the chitin synthesis and 
prevented the normal deposition of new cuticle during apolysis leading to the production of pupal deformities [19].

In the current investigation on $P$. unionalis, Novaluron exhibited a disruptive effect on the metamorphosis program, since larval-pupal intermediates had been produced, after treatment of newly moulted last instar larvae with some concentrations. This feature of impaired metamorphosis was, also, described as abnormal or lethal pupation [124]. Our result was, to a great extent, in agreement with some of those reported results of disturbed metamorphosis of a number of insect pests by various IGRs, such as $H$. armigera by Hexaflumuron [101], S. littoralis by Novaluron [55] and Cyromazine [78], C. cephalonica by Fenoxycarb [94] and P. gossypiella by Novaluron [56]. Also, the larval-pupal intermediates were observed after topical treatment of last instar larvae of Spodoptera exempta, Spodoptera exigua, S. littoralis, Mamestra brassicae, Galleria mellonella, Mythimna unipuncta and Spodoptera frugiperda with RH-5849, Tebufenozide or Methoxyfenozide [143, 113, 116]. Moreover, some pupal-adult intermediates of $P$. unionalis had been produced only at $0.01 \mathrm{ppm}$ of Novaluron, in the current investigation, as a feature of impaired metamorphosis program. As far as our literature survey could ascertain, no information was available on the production of pupal-adult intermediates.

The production of larval-pupal and pupal-adult intermediates, in the present study on P. unionalis, indicated the disturbance of metamorphosis program by Novaluron. It can be interpreted by the interference of Novaluron with the hormonal regulation of pupation program [110]. For some detail, some conceivable scenarios can be described herein. (1) Novaluron may inhibit the metamorphosis program via an ecdysteroid reduction, interference with the release of eclosion hormone or/and inhibition of the neurosecretion (PTTH) [144]. (2) The production of these intermediates may indicate a juvenile property of Novaluron retarding the perfect larval-pupal or/and pupal-adult transformation. These mosaic creatures are unusual and died soon after formation. (3) The production of intermediate creatures in $P$. unionalis can be explicated by an inhibitory effect of Novaluron on the DNA synthesis [145] or the chitin biosynthesis and chitin synthase [146]. (4) The molt induction had lethal consequences because the induction of a rapid molt did not provide enough time for the completion of larval-pupal transformation. Thus, the insects molted to nonviable forms between the life stages [147]. Molts induced during the early phase of the last instar produce larval-like individuals, while those formed in the late phase generate pupal-like individuals [148].

\section{CONCLUSION}

Depending on results of the present study, it can be concluded that Novaluron exhibited various degrees of toxicity against all developmental stages of $P$. unionalis, as well as it displayed some disruptive effects on development, metamorphosis and pupal morphogenesis. Therefore, Novaluron may be considered as a promising control agent against this economic pest of the commercial olive groves in Egypt and other olive producing countries as a potential alternative to the conventional pesticides.

\section{References}

[1] M.E. Tzanakakis, "Seasonal development and dormancy of insects and mites feeding on olive: a review". Netherlands J. Zool., 2003, vol. 52, pp. 87-224.

[2] H. Noori and J. Shirazi, "A study on some biological characteristics of olive leaf moth, Palpita unionalis Hübner (Lep.: Pyralidae)". Iran. J. Agric. Sci. Tech., 2012, vol. 14, no. 2, pp. 257-266. 
[3] T. Broumas, G. Haniotakis, C. Liaropoulos, T. Tomazou and N. Ragoussis, "The efficacy of an improved form of the mass-trapping method, for the control of the olive fruit fly, Bactrocera oleae (Gmelin) (Dipt., Tephritidae), pilot-scale feasibility studies". J.App. Entomol., 2002, vol. 126, no. 5, pp. 217-223.

[4] W.A. Shehata, S.S. Abou-Elkhair, A.A. Youssef, and F.N. Nasr, "Biological studies on the olive leaf moth, Palpita unionalis Hübner (Lepid., Pyralidae), and the olive moth, Prays oleae Bernard (Lepid., Yponomeutidae)". Journal of Pest Science, 2003, vol. 76, no. 6, pp. 155-158.

[5] Ç. Yilmaz, and H. Genç, "Determination of the life cycle of the olive fruit leaf moth, Palpita unionalis (Lepidoptera: Pyralidae) in the Laboratory". Florida Entomologist, 2012a, vol. 95, no. 1, pp. 162-170.

[6] Ç. Yilmaz, and H. Genç, "Egg production and adult longevity of the olive leaf moth, Palpita unionalis Hubner (Lepidoptera: Pyralidae) on selected adult diets". J. Tekirdag Faculty Agric., 2012b, vol. 9, no. 1, pp. 1-5.

[7] M. Pinto, and G. Salemo, "The olive pyralid". Informator, Agrio., 1995, vol. 51, no. 43, pp. 77-81.

[8] S. Grossley, "Palpita unionalis". 2000, Retrived April, 2001, Available from http://www.nysaes. cornell.edu/fst/faculty/ acree/pheromet/ ins/ palpiunion.html

[9] S.M. Foda, A.M. Awadallah, and M.R. Abou-ElGhar, "Chemical control of the olive moth Palpita unionalis Hb". Agric. Res. Rev., 1976, vol. 54, no.2,pp. 153-159.

[10] A.S. Fodale, and R. Mule, "Bioethological observations on Palpita unionalis $\mathrm{Hb}$ " in Sicily and trials of defence. Acta Horticul., 1990, no. 286, pp. 351-353.
[11] B.A. Montiel and O. Jones, "Alternative methods for controlling the olive fly, Bactrocera oleae, involving semiochemicals". Proceedings of Pheromones and Other Biological Techniques for Insect Control in Orchards and Vineyards. IOBC/ WPRS Bull., 2002, vol. 25, no. 9, pp. 147-156.

[12] T.G.E. Davies, L.M. Field, P.N.R. Usherwood, and M.S. Williamson, "DDT, pyrethrins and insect sodium channels". IUBMB Life., 2012, no. 59, pp. 151-162.

[13] H. Mosallanejad and G. Smagghe, "Biochemical mechanisms of methoxyfenozide resistance in the cotton leafworm Spodoptera littoralis". Pest Manage. Sci., 2009, no. 65, pp. 732-736.

[14] L.G. Costa, G. Giordano, M. Guizzetti, and A. Vitalone, "Neurotoxicity of pesticides: a brief review". Frontiers BioSci., 2008, no. 13, pp. 1240-1249.

[15] R.A. Relyea, (2009): "A cocktail of contaminants: how mixtures of pesticides at low concentrations affect aquatic communities". Oecologia., 2009, no. 159, pp. 363-376.

[16] T.S. Dhadialla, G.R. Carlson, and D.P. Le, "New insecticides with ecdysteroidal and juvenile hormone activity". Annu. Rev. Entomol., 1998, no. 43 , pp. 545-569.

[17] I. Ishaaya; S. Kontsedalov, and A.R. Horowitz, "Biorational insecticides: mechanism and crossresistance". Arch. Insect Biochem. Physiol., 2005, no. 58, pp. 192-199.

[18] I. Khan and A. Qamar, "Andalin, an insect growth regulator, as reproductive inhibitor for the red cotton stainer, Dysdercus koenigii (F.) (Hemiptera: Pyrrhocoridae)". Acad. J. Entomol., 2012, vol. 5, no. 2, pp. 113-121.

[19] A. Retnakaran, J. Granett and T. Andennis, "Insect growth regulators". In: "Comprehensive Insect, Physiology, Biochemistry and 
Pharamacology"(Kerkut G.A. and Gibert L.I., eds.). Pergamon, Oxford , 1985, no. 12, pp. 529-601.

[20] D.J. Biddinger, and L.A. Hull, "Effect of several types of insecticides on the mite predator Stethorus punctum (Coleoptera: Coccinellidae), including insect growth regulators and abamectin". J. Econ. Entomol., 1995, no. 88, pp. 358-366.

[21] K.H. Hoffman, and M.W. Lorenz, "Recent advances in hormones in insect pest control. Phytoparasitica", 1998, vol. 26, no. 4, pp. 323330.

[22] A.H. Nicholas; W.G. Thwaite, and R.N. Spooner-Hart, "Arthropod abundance in a disruption and supplementary insecticide treatments for codling moth, Cydia pomonella (L) (Lepidoptera: Torticidae". Austral. J.Entomol., 1999, no. 38, pp. 23-29.

[23] F. Martins, and I.G. Silva, (2004): "Avaliação da atividade inibidora do di-flubenzuron na ecdise das larvas de Aedes aegypti (Linnaeus, 1762) (Diptera, Culicidae". Rev. Soc. Bras. Med. Trop., 2004, no. 37, pp. 135-138.

[24] Q.L. Wang, and T.-X. Liu, "Effects of three insect growth regulators on Encarsia formosa (Hymenoptera: Aphelinidae), an endoparasitoid of Bemisia tabaci (Hemiptera: Aleyrodidae". Journal Econ. Entomol., 2016, vol. 0, no. 0, pp. $1-8$.

[25] J. Wu, "The application of IGRs in agricultural pest control". Pestic., 2002, no. 41, pp. 6-8.

[26] G. Cedric, "Insects and humans". Anon (eds.). Entomology, $3^{\text {rd }}$ Edition. Springer, Dordrecht, 2005 , pp. $725-782$.

[27] Y. Wang, and M. Wang, "The research of IGRs". World Pestic., 2007, no. 29, pp. 8-11.
[28] P.K.R. Nair, "An introduction to Agroforestry". Kluwer Academic Publishers, in collaboration with International Centre for Research in Agroforestry, 1993, 499 pp.

[29] C. Resmitha and K.V. Meethal, "Toxicity of insect growth regulator, Pyriproxyfen, on larvae of Spodoptera mauritia Boisd. (Lepidoptera: Noctuidae". Int. J. Agric. Innov. Res., 2016, vol. 5, no.1, pp. 173-176.

[30] H.D. Wing and H.E. Aller, "Ecdysteroid agonists as novel insect regulators". In: "Pesticides and alternatives" (Casida J.E., ed.). Elsevier Science Publishers B.V., Amsterdam, 1990, pp. 251-257.

[31] H. Oberlander and D. Silhacek, "Insect growth regulators", In: "Alternatives to pesticides in stored-product IPM" (Subramanyam B. and Hagstrum D.W., eds.). Kluwer Academic Publishers, Boston, 2000 pp.147-163.

[32] H. Tunaz and N. Uygun, "Insect growth regulators for insect pest control". Turkish J. Agric. Forestry., 2004, no. 28, pp. 337-387.

[33] K. Mondal and S. Parween, "Insect growth regulators and their potential in the management of stored-product insect pests". Integr. Pest Manage. Rev., 2000, no. 5, pp. 255-295.

[34] L.S. Talikoti, D. Sridevi and T. Ratnasudhakar, "Relative toxicity of insect growth regulators against tobacco caterpillar, Spodoptera litura (Fabricius)". J. Entomol. Res., 2012, vol. 36, no. 1, pp. 31-34.

[35] M.S. Mulla, A. Tawatsin, J. Chompoosri, M. Zaim and T. Su, "Laboratory and field evaluation of novaluron a new acylurea insect growth regulator against Aedes aegypti (Diptera: Culicidae". J.Vector Ecol., 2003, no. 4, pp. 241254. 
[36] I. Ishaaya, A. Barazani, S. Kontsedalov and A.R. Horowitz, "Insecticides with novel modes of action: mechanism, selectivity and crossresistance". Entomol. Res., 2007, no. 37, pp. 148-152.

[37] H. Cetin, F. Erler and A. Yanikaglu, "Larvicidal activity of novaluron, a chitin synthesis inhibitor, against the housefly, Musca domestica". J. Insect Sci., 2006, no. 6, pp. 344-351.

[38] T.M. Mascari, M.A. Mitchell, E.D. Rowton and L.D. Foil, "Evaluation of Novaluron as a feedthrough insecticide for control of immature sand flies (Diptera: Psychodidae)". J. Med. Entomol., 2007, vol. 44, no. 4, pp. 714-717.

[39] E.N. Nwankwo, N.J. Okonkwo, N.A. Ozumba and E.G. Okafor, "Comparative studies on the larvicidal action of Novaluron (Mosquiron ${ }^{\circledR} 100$ EC) and Moringa oliefera (LAM) seed oil against Aedes aegypti (Diptera: Culicidae) larvae". Afr. Res. Rev., 2011, vol. 5, no. 1, pp. 424-437.

[40] A. Bouaziz, H. Boudjelida and N. Soltani, "Toxicity and perturbation of the metabolite contents by a chitin synthesis inhibitor in the mosquito larvae of Culiseta longiareolata". Ann. Biol. Res., 2011, vol. 2, no. 3, pp. 134-143.

[41] N.G. Fontoura, D.F. Bellinato, D. Valle and J.B.P. Lima, "The efficacy of a chitin synthesis inhibitor against field populations of organophosphate-resistant Aedes aegypti in Brazil". Mem. Inst. Oswaldo Cruz, Rio de Janeiro, 2012, vol. 107, no. 3, pp. 387-395.

[42] N. Djeghader, H. Djeghader, A. Bouaziz and N. Soltani, "Biological effects of a benzoylphenylurea derivative (Novaluron) on larvae of Culex pipiens (Diptera: Culicidae)"; Adv. App. Sci. Res., 2013, vol. 4, no. 4, pp. 449456.
[43] I. Ishaaya, S. Kontsedalov, D. Masirov and A.R. Horowitz, "Bio-rational agents-mechanism, selectivity and importance in IPM programs for controlling agricultural pests". Med. Landbouww Rijksuniv Gent, 2001, no. 66, pp. 363-374.

[44] I. Ishaaya, A.R. Horowitz, L. Tirry and A. Barazani, "Novaluron (Rimon), a novel IGR: mechanism, selectivity and importance in IPM programs". Proc. Int. Symp. Crop Protect. Med. Fac. Landbouww Univ., 2002, Gent, no. 67, pp. 617-626.

[45] I. Ishaaya, S. Kontsedalov and A.R. Horowitz, "Novaluron (Rimon), a novel IGR: potency and cross-resistance". Arch. Insect Biochem. Physiol., 2003, no. 54, pp. 157-164.

[46] K.L. Kamminga, T.P. Kuhar, A. Wimer and D.A. Herbert, "Effects of the insect growth regulators novaluron and diflubenzuron on the brown marmorated stink bug". Plant Health Progress Online doi:10.1094/PHP-2012-1212-01-RS, 2012.

[47] M. Portilla, G. Snodgrass and R. Luttrell, "A Novel bioassay using a non-autoclaved solid Lygus diet to evaluate the effect of Beauveria bassiana and the insect growth regulator novaluron on tarnished plant bug, Lygus lineolaris". The $3^{\text {rd }}$ international Lygus symposium, Scottsdale, Arizona, USA, 2012.

[48] G.C. Cutler, C.D. Scott-Dupree, J.H. Tolman and C.R. Harris, "Field efficacy of novaluron for control of Colorado potato beetle (Coleoptera: Chrysomelidae) on potato". Crop Protec., 2007, no. 26 , pp. $760-767$.

[49] A. Alyokhin, R. Guillemette and R. Choban, "Stimulatory and suppressive effects of Novaluron on the Colorado potato beetle reproduction". J. Econ. Entomol., 2009, vol. 102, no.6, pp. 2078-2083. 
[50] F.H. Arthur and E.A. Fontenot, "Residual activity of methoprene and novaluron as surface treatments to manage the flour beetles, Tribolium castaneum and Tribolium confusum". J. Insect Sci., 2012, vol. 12, pp. 12- 95.

[51] K.S.R.K. Murthy and G.M. Ram, "Studies on the efficacy of a new chitin synthesis inhibitor Rimon (novaluron 10 EC) on American bollworm Helicoverpa armigera Hubn. attacking cotton". In: "Resources management in plant protection during twenty first century", Hyderabad, India, 14-15 November 2002 (Babu B.S., Varaprasad K.S., Anitha K., Prasada Rao R.D.V.J., Chakrabarty, S.K. and Chandurkar P.S., eds.)., 2002, vol. II, pp.: 165-168.

[52] A.J. Martins, T.A. Belinato, J.B. Lima and D. Valle, "Chitin synthesis inhibitor effect on Aedes aegypti populations susceptible and resistant to organophosphate temephos". Pest Manage. Sci., 2008, no. 64, pp. 676-680.

[53] L.C. Farnesi, J.M. Brito, J.G. Linss, M. PelajoMachado, D. Valle and G.L. Rezende, "Physiological and morphological aspects of Aedes aegypti developing larvae: effects of the chitin synthesis inhibitor Novaluron" PLoS ONE., 2012 vol. 7, no.1, e30363. doi:10.1371/journal.pone.0030363.

[54] K.H. Lohmeyer, J.M. Pound, K.M. Yeater and M.A. May, "Efficacy of Novaluron as a feedthrough for control of immature horn flies, house flies, and stable flies (Diptera: Muscidae) developing in cow manure". J. Medical Entomol., 2014, vol. 51, no.4, pp. 725-906.

[55] K. Ghoneim, M. Tanani, Kh. Hamadah, A. Basiouny and $\mathrm{H}$. Waheeb, "Bioefficacy of Novaluron, a chitin synthesis inhibitor, on survival and development of Spodoptera littoralis (Boisd.)(Lepidoptera: Noctuidae)". J. Adv. Zool., 2015, vol. 1, no. 1, pp. 24-35.
[56] K. Ghoneim, H.A. Hassan, M.A. Tanani and N.A. Bakr, "Toxic and disruptive effects of Novaluron, a chitin synthesis inhibitor, on development of the pink bollworm Pectinophora gossypiella (Saunders)(Lepidoptera: Gelechiidae)". Int. J. Entomol. Res., 2017, vol. 2, no. 2, pp. 36-47.

[57] H.A. Hassan, K. Ghoneim, M.A. Tanani and N.A. Bakr, "Impairing effectiveness of the chitin synthesis inhibitor, Novaluron, on adult performance and reproductive potential of the pink bollworm Pectinophora gossypiella (Saunders) (Lepidoptera: Gelechiidae)." J. Entomol. Zool. Studies, 2017, vol. 5, no.2, pp. 581-592.

[58] M.A. Tanani, K. Ghoneim, H.A. Hassan and N.A Bakr, "Perturbation of main body metabolites in the pink bollworm Pectinophora gossypiella (Saunders) (Lepidoptera: Gelechiidae) by the chitin synthesis inhibitors Novaluron and Diofenolan." BioBulletin, 2017, vol. 3, no. 3 (In press).

[59] K. Ghoneim, H.A. Hassan, M.A. Tanani and Bakr, "Deteriorated larval haemogram in the pink bollwor N.A. m Pectinophora gossypiella (Saunders) (Lepidoptera: Gelechiidae) by the chitin synthesis inhibitors, Novaluron and Diofenolan." Int. J. Modern Res. Rev., 2017, vol. 5, no. 2, pp. 1487-1504.

[60] F.M. Malhat, N.M. Loutfy and M.T. Ahmed, "Dissipation kinetics of novaluron in tomato, an arid ecosystem pilot study." Toxicological \& Environmental Chemistry, 2014, vol. 96, no. 1, pp. 41-47.

[61] A. Barazani, "Rimon, an IGR insecticide". Phytoparasitica, 2001, no. 29, pp. 59-60.

[62] I. Ishaaya and A.R. Horowitz, "Novaluron (Rimon), a novel IGR: its biological activity and importance in IPM programs." Phytoparasitica, 2002, no. 30, pp. 203-206. 
[63] A.N. Mansour, "Biocontrol studies on using Bracon sp. (Hymenoptera: Braconidae) to control lepidopterous pests infesting olive trees". Ph. D. Thesis, Fac. Sci., Al-Azhar Univ., Egypt, 2012, 176 pp.

[64] W.S. Abbott, "A method of computing the effectiveness of insecticide". J. Econ. Entomol., 1925, vol. 18, no.2, pp. 265-267.

[65] D.J. Finney "Probit analysis". $3^{\text {rd }}$ ed. Cambridge, England: Cambridge University Press, 1971, $318 \mathrm{pp}$.

[66] G.P. Waldbauer, "The consumption and utilization of food by insects". Advances in Insect Physiology, 1968, no. 5, pp. 229-288.

[67] C. Dempster, "The population dynamic of Moroccan locust Dociostarus murcocamus in Cyprus". Anti Locust Bull., 1957, p. 27.

[68] A.G. Richard, "Cumulative effects of optimum and suboptimum temperatures on insect development". In: "Influence of Temperature on Biological Systems". (Johnson F.H., ed.). Am. Physiol. Soc., 1957, no. 15, pp 35-38.

[69] M.J. Moroney, "Facts from figures ( $3^{\text {rd }}$ ed.)." Penguin Books Ltd., 1956, Harmondsworth. Middle Sex.

[70] S.A. Aref, O.Ch. Bayoumi and H.A.B. Soliman, " Effect of certain insecticides on the biotic potential of the cotton leafworm, Spodoptera littoralis (Boisd.)". Egypt. J. Agric. Res., 2010, vol. 88 , no.1, pp. 31-40.

[71] R.F.A. Bakr, N.M. El-barky, M.F. Abd Elaziz, M.H. Awad and H.M.E. Abd El-Halim, "Effect of chitin synthesis inhibitors (flufenoxuron) on some biological and biochemical aspects of the cotton leaf worm Spodoptera littoralis Bosid". (Lepidoptera: Noctuidae). Egypt. Acad. J. Biolog. Sci., 2010, vol. 2, no.2, pp. 43-56.
[72] J.B.A. El-Naggar, "Sublethal effect of certain insecticides on biological and physiological aspects of Spodoptera littoralis (Boisd.)". Nature and Science, 2013, vol. 11, no. 7, pp. 19-25.

[73] I. Gaaboub, S. Halawa and A. Rabiha, "Toxicity and biological effects of some insecticides, IGRs and Jojoba oil on cotton leafworm Spodoptera littoralis (Boisd.)". J. App. Sci. Res., 2012, no. vol. 2, pp. 131-139.

[74] R.F.A. Bakr, M.F. Abd Elaziz, N.M. El-barky, M.H. Awad and H.M.E. Abd El-Halim, "The activity of some detoxification enzymes in Spodoptera littoralis (Boisd.) Larvae (Lepidoptera Noctuidae) treated with two different insect growth regulators." Egypt. Acad. J. Biolog. Sci., 2013, vol. 5, no. 2, pp. 19-27.

[75] H.M. Nasr, M.E.I. Badawy and E.I. Rabea, "Toxicity and biochemical study of two insect growth regulators, buprofezin and pyriproxyfen, on cotton leafworm Spodoptera littoralis". Pestic. Biochem. Physiol., 2010, vol. 98, no. 2, pp. 198-205.

[76] M. Ragaei and K.H. Sabry, "Impact of spinosad and buprofezin alone and in combination against the cotton leafworm, Spodoptera littoralis under laboratory conditions". J. Biopesticides, 2011, vol. 4 , no. 2 , pp. 156-160.

[77] S. Pineda, F. Budia; M.I. Schneider, A. Gobbi, E. Vinuela, J. Valle and P. del Estal, "Effects of two biorational insecticides, spinosad and methoxyfenozide, on Spodoptera littoralis (Lepidoptera: Noctuidae) under laboratory conditions". J. Econ. Entomol., 2004, no. 97 pp. 1906-1911.

[78] M. Tanani, Kh. Hamadah, K. Ghoneim, A. Basiouny and $\mathrm{H}$. Waheeb, "Toxicity and bioefficacy of Cyromazine on growth and development of the cotton leafworm Spodoptera 
littoralis (Lepidoptera: Noctuidae)". Int. J. Res. Studies in Zool., 2015, vol. 1, no.3, pp.1-15.

[79] S. Singh and K. Kumar, "Diofenolan: a novel insect growth regulator in common citrus butterfly, Papilio demoleus". Phytoparasitica, 2011, vol. 39, no. 3, pp. 205-213.

[80] M. Mojaver and A.R. Bandani, "Effects of the insect growth regulator pyriproxyfen on immature stages of sunn pest, Eurygaster integriceps Puton (Heteroptera: Scutelleridae)". Munis Entomol. Zool., 2010, vol. 5, no. 1, pp. 187-197.

[81] I. Khan, and A. Qamar, "Biological activity of andalin (flucycloxuron), a novel chitin synthesis inhibitor, on red cotton stainer Dysdercus koenigii (Fabricius)". Frontiers in Life Sciences: Basic and Applied, Biology and Medicine, 2011, vol. 3, no. 2, pp. 324-335.

[82] F. Perveen, "Biochemical analyses of action of chlorfluazuron as reproductive inhibitor in Spodoptera litura". In: "Insecticides- Advances in Integrated Pest Management". (Perveen F., ed.) Publisher: InTech, 2012, pp. 293-326.

[83] B.-Z. Hu, Y. Xu, X.-R. Zheng and W.-P. Shi, "Molt disruption and mortality of Locusta migratoria var. manilensis (Meyen) (Orthoptera: Acrididae) caused by insect growth regulators". Afr. J. Biotechnol., 2012, vol. 11, no.16, pp. 3882-3887.

[84] K. Hamaidia and N. Soltani, "Laboratory evaluation of a biorational insecticide, Kinoprene, against Culex pipiens larvae: effects on growth and development". Annu. Res. Rev. Biol., 2014, vol. 4, no. 14, pp. 2263-2273.

[85] N.A. Khatter, "Effect of two insect growth regulators on the development of Agrotis ipsilon Hufn. (Lepidoptera: Noctuidae)." J. Harmon. Res. App. Sci., 2014, vol. 2, no. 1, pp. 20-28.
[86] K. Kaur and A.K. Chandi,"Toxicity of Pyriproxyfen against Tobacco caterpillar, Spodoptera litura (Fabricius)". Int. J. Sci. Res., 2015, vol. 4, no. 11, pp. 481-483.

[87] P. Gado; S.G. Salokhe and S.G. Deshpande, "Impact of Lufenuron $(5.4 \%$ EC) on reproductive end points of Tribolium castaneum". World J. Pharmaceut. Res., 2015, vol. 4, no. 3, pp. 15931599.

[88] Q. Ali, M. ulHasan, L.J. Mason, M. Sagheer and N. Javed, "Biological activity of insect growth regulators, Pyriproxyfen, Lufenuron and Methoxyfenozide against Tribolium castaneum (Herbst)". Pakistan J. Zool., 2016, vol. 48, no. 5, pp. 1337-1342.

[89] K. Hamaidia and N. Soltani, "Ovicidal activity of an insect growth disruptor (methoxyfenozide) against Culex pipiens L. and delayed effect on development". J. Entomol. Zool. Studies, 2016, vol. 4, no. 4, pp. 1202-1207.

[90] A. Tazir, L. Kirane-Amrani and N. Soltani, "Impact of two bisacylhydrazines on development of Ephestia kuehniella Zeller, 1879 (Lepidoptera: Pyralidae) with respect to cuticular thickness and protein". J. Entomol. Zool. Studies, 2016, vol. 4, no. 6, pp. 626-631.

[91] F.P. Aliabadi, A. Sahragard and M. Ghadamyari, "Lethal and sublethal effects of a chitin synthesis inhibitor, lufenuron, against Glyphodes pyloalis Walker (Lepidoptera: Pyralidae)". J. Crop Prot., 2016, vol. 5, no. 2, pp. 203-214.

[92] L.M. Vivan, J.B. Torres and P.L.S. Fernandes, "Activity of selected formulated biorational and synthetic insecticides against larvae of Helicoverpa armigera (Lepidoptera: Noctuidae)". J. Econ. Entomol. 2016, tow244. doi: https://doi.org/10.1093/jee/tow244

[93] A. Singh and S.K. Tiwari, "Role of Fenoxycarb, a juvenile hormone analogue, on the 
developmental stages of rice-moth, Corcyra cephalonica Staint. (Lepidoptera: Pyralidae)". Int. J. Zool. Investig., 2016, vol. 2, no. 2, pp. 267-280.

[94] R. Begum and A. Qamar, "Fenoxycarb- a potent inhibitor of metamorphosis and reproduction in Rice Moth, Corcyra cephalonica (Stainton)". J. Entomol. Zool. Studies, 2016, vol. 4, no.4, pp. 572-577.

[95] M.A. Khan, "Efficacy of insect growth regulator Buprofezin against Papaya mealy bug". J. Entomol. Zool. Studies, 2016, vol. 4, no. 4, pp. 730-733.

[96] M.K. Rust and W.L.H. Hemsarth, "Intrinsic activity of IGRs against larval cat fleas". J. Medical Entomol., 2016, vol. 0, no. 0, 1-4. doi: 10.1093/jme/tjw201

[97] G.Z. Khan, I. Khan, I.A. Khan, Alamzeb, M. Salman and Kalim Ullah, "Evaluation of different formulations of IGRs against Aedes albopictus and Culex quinquefasciatus (Diptera: Culicidae)". Asian Pacific J. Tropical Biomedicine, 2016, vol. 6, no. 6, pp. 485-491.

[98] Jr.W.A. Donahue, A.T. Showler, M.W. Donahue, B.E. Vinson and W.L.A. Osbrink, "Lethal effects of the insect growth regulator Cyromazine against three species of filth flies, Musca domestica, Stomoxys calcitrans, and Fannia canicularis (Diptera: Muscidae) in cattle, swine, and chicken manure". J. Econ. Entomol., 2017, tow294. doi: https://doi.org/10.1093/jee/tow294

[99] K.H. Sabry and G.Y. Abdou, "Biochemical and toxic characterization of some insect growth regulators to the pink bollworm, Pectinophora gossypiella (Saunders)". American-Eurasian J. Sustain. Agric., 2016, vol. 10, no. 1, pp. 8-14.

[100] S.C. Sharma and A. Pathania, "Susceptibility of tobacco caterpillar, Spodoptera litura (Fabricius) to some insecticides and biopesticides". Indian J. Sci. Res. Technol., 2014, no. 2, pp. 24-30.

[101] M. Taleh, R.F. Pourabad, J. Geranmaye and A. Ebadollahi, "Toxicity of Hexaflumuron as an insect growth regulator (IGR) against Helicoverpa armigera Hubner (Lepidoptera: Noctuidae)". J. Entomol. Zool. Studies, 2015, vol. 3, no.2, pp. 274-277.

[102] H. Merzendorf and L. Zimoch, "Chitin metabolism in insects: structure, function and regulation of chitin synthases and chitinases". J. Exp. Biol., 2003, no. 206, pp. 4393-4412.

[103] H. Merzendorf, " Insect chitin synthases: a review". J. Comp. Physiol. B, 2005, no. 176, pp. $1-15$.

[104] M. Eto, "Biochemical mechanism of insecticidal activities". In: "Chemistry of Plant Protection"(Haug G. and Hoffman H., eds.). Springer Verlag, 1990, no. 6, pp. 65- 107.

[105] S.M. Abdel Rahman, E.M. Hegazy and A.E Elweg, "Direct and latent effect of two chitin synthesis inhibitors on Spodoptera littoralis larvae (Boisd.)". American Eurasian J. Agric.Environ.Sc., 2007, vol. 2, no. 4, pp. 454464.

[106] M.M. Adel, "Lufenuron impair the chitin synthesis and development of Spodoptera littoralis Bosid. (Lepidoptera: Noctuidae)". J. App. Sci. Res., 2012, vol. 8, no. 5, pp. 27-66.

[107] J. Zorzetti, K. Constanski, P.H. Santoro, I.C.B. Fonseca and P.M.O.J. Neves, "Growth regulator insecticides for the control of the lesser mealworm beetle Alphitobius diaperinus (Coleoptera: Tenebrionidae)". Revista Colombiana de Entomología, 2015, vol. 41, no. 1, pp. 24-32.

[108] Y.M. Linton, A.J. Nisbet and A.J. Mordue (Luntz), "The effect of azadirachtin on the testes of the desert locust Schistocerca gregaria 
(Forskal)". J. Insect Physiol., 1997, no. 43 pp. 1077-1084.

[109] K.S. Ghoneim, H.A. Mohamed and A.S. Bream, "Efficacy of the neem seed extract, Neemazal, on growth and development of the Egyptian cotton leafworrn, Spodoptera littoralis Boisd. (Lepidoptera: Noctuidae)". J. Egypt. Ger. Soc. Zool., 2000, no. 33, pp. 161-179.

[110] Z. Al-Sharook, K. Balan, Y. Jiang and H. Rembold, "Insect growth inhibitors from two tropical Meliaceae: Effects of crude seed extracts on mosquito larvae". J. App. Entomol. 1991, no. 111, pp. 425-430.

[111] H. Oberlander, D. Silhacek, E. Shaaya and I. Ishaaya, "Current status and future perspectives of the use of insect growth regulators for the control of stored product insects". J. Stored Prod. Res., 1997, no. 33, pp. 1-6.

[112] N.E.H. Djeghader, L. Aïssaoui, K. Amira and H. Boudjelida, "Impact of a chitin synthesis inhibitor, Novaluron, on the development and the reproductive performance of mosquito Culex pipiens". World App. Sci. J., 2014, vol. 29, no. 7, pp. 954-960.

[113] G. Smagghe and D. Degheele, "The significance of pharmacokinetics and metabolism to the biological activity of RH5992 (tebufenozide) in Spodoptera exempta, Spodoptera exigua and Leptinotarsa decemlineata". Pest. Biochem. Physiol., 1994, no. 49, pp. 224-234.

[114] E.E. Osman, I. Rarwash and M.M. ElSamadisi, "Effect of the anti-moulting agent "Dimilin" on the blood picture and cuticle formation in Spodopterea littoralis (Boisd.) larval". Bull. Entomol. Soc. Egypt (Econ. Ser.), 1984, no. 14, pp. 3-46.

[115] P. Armbruster and R.A. Hutchinson, "Pupal mass and wing length as indicators of fecundity in Aedes albopictus and Aedes geniculatus (Diptera: Culicidae)". J. Med. Entomol., 2002, no. 39, pp. 699-704.

[116] A. Gobbi, F. Budia, M. Schneider, P. del Estal, S. Pineda and E. Viñuela,"Tebufenozide effects on Spodoptera littoralis (Boisduval), Mythimna unipuncta (Haworth) and Spodoptera exigua (Hübner)". Boletín de Sanidad Vegetal, Plagas, 2000, vol. 26, no. 1, pp. 119-127.

[117] A.A. Barrania, "Antifeedant, growth inhibitory and toxicity effects of chlorantraniliiprole, thiamethoxam and novaluron against the cotton leafworm, Spodoptera littoralis (Boisd.)(Lepidoptera: Noctuidae) in cotton fields". Egypt. J. Agric. Res., 2013, vol. 91, no. 3, pp. 903-911.

[118] E. Viňuela, F. Budia, J. Gacas, A. Adan, M. Marco and P. Del Estal, "Differential larval age susceptibility of Medfly Ceratitis capitata to cyromazine". J. App. Entomol., 1993, no. 115, pp. 355-361.

[119] K.S. Ghoneim, M.A. Fouda and A.S. Bream, "Effectiveness of the non-steroidal ecdysone mimic, RH-5849, for the control of Musca domestica vicina". J.Egypt.Soc.Parasitol., 1991, vol. 21, no. 3, pp. 723-733.

[120] B. Darvas, L. Polgar, H.T. El-Din, K. Eröss and K.D. Wing, "Developmental disturbances in different insect orders caused by an ecdysteroid agonist, RH 5849". J. Econ. Entomol., 1992, no. 85, pp. 2107-2112.

[121] A.M. Tanani, "Study the effects of certain IGRs and plant extracts on some physiological aspect of the Rhyncophorus ferrugenius (Curculionidae: Coleoptera)". M.Sc. Thesis, Fac. Sci., Al-Azhar Univ., Egypt, 2001.

[122] T.A.A. El-Sheikh, "Effects of application of selected insect growth regulators and plant extracts on some physiological aspects of the 
black cutworm, Agrotis ipsilon (HUF.)". Ph. D. Thesis, Fac. Sci., Ain Shams Univ., Egypt, 2002.

[123] R.F. Bakr, K.S. Ghoneim, A.G. Al-Dali, M.A. Tanani and A.S. Bream, "Efficiency of the chitin synthesis inhibitor lufenuron (CGA-184699) on growth, development and morphogenesis of Schistocerca gregaria (Orthoptera: Acrididae)". Egypt. Acad. J. Biol. Sci., 2008, vol. 1, no. 1, pp. 41-57.

[124] N. Zarate, O. Diaz, A.M. Martinez, J.I. Figueroa, M.I. Schneider, G. Smagghe, E. Vinuela, F. Budia and S. Pineda, "Lethal and sublethal effects of Methoxyfenozide on the development, survival and reproduction of the fall armyworm, Spodoptera frugiperda (J.E. Smith) (Lepidoptera: Noctuidae)". Neotrop. Entomol., 2011, vol. 40, no. 1, pp. 129-137.

[125] M.A. Barnby and J.A. Klocke, "Effects of azadirachtin on levels of ecdysteroids and prothoracicotropic hormone-like activity in Heliothis virescens (Fabr.) larvae". J. Insect Physiol., 1990, no. 36, pp. 125-131.

[126] M. Nasiruddin and A.J. Mordue (Luntz), "The protection of barley seedlings from attack by Schistocerca gregaria using azadirachtin and related analogues". Entomol. Exp. App., 1994, no. 70 , pp. 247-252.

[127] T.H. Karam, "Toxicity and some aspects of the action of IGRs and botanical essential oils on the cotton leafworm Spodoptera littoralis (Boisd.) (Lepidoptera: Noctuidae)". J. Egypt. Ger. Soc. Zool., 2000, no. 33(E), pp. 81-91.

[128] A.A.M. Kandil, T.R. Abd El-Zhar and A.M. Rashad, "Some biological and biochemical effects of chitin synthesis inhibitor on pink bollworm Pectinophora gossypiella". Annals of Agric. Sc. Moshtohor (Egypt), 2005, vol. 43, no. 4, pp. 1991-2002.
[129] H.S. Al-Kazafy, "Effect of some pesticides with different target sites on the pink bollworm, Pectinophora gossypiella (Saunders)". Arch. Phytopathol. Plant Protec., 2013, vol. 46, no. 8, pp. 942-951.

[130] E.F. El-Khayat, A.M. Rashad, T.R. Abd-El Zaher, A.M. Shams El-Din and H.S. Salim, "Toxicoloical and biological studies of some pesticidal formulations against Pectinophora gossypiella (Saunders) (Lepidoptera: Gelechiidae)". American-Eurasian J. Toxicol. Sci., 2015, vol. 7, no. 1, pp. 01-06.

[131] M.S.M. Salem, "Latent effect of different compounds on Pectinophora gossypiella (Saunders)". J. Plant Prot. and Path., Mansoura Univ., Egypt, 2015, vol. 6, no. 2, pp. 269-279.

[132] G.-P. Song, D.-K. Hu1, H. Tian, Y.-S. Li, Y.-S. Cao, H.-W. Jin and Z.-N. Cui, "Synthesis and larvicidal activity of novel thenoylhydrazide derivatives". Scientific Reports, 2016, no. 6, 22977, 13pp., DOI: 10.1038/srep22977

[133] B. Subrahmanzam, T. Müller and H. Rembold, "Inhibition of turnover of neurosecretion by azadirachtin in Locusta migratoria". J. Insect Physiol., 1989, no. 35 pp. 493-500.

[134] E. Kuwano, N. Fujita, K. Furuta and N. Yamada "Synthesis and biological activity of novel antijuvenile hormone agents". J. Pestic. Sci., 2008, vol. 33 , no. 1 , pp. 14-16

[135] S. Pineda, A.M. Martinez, J.I. Figueroa, M.I. Schneider, P. Del. Estal, E. Vinuela, B. Gomez, G. Smagghe and F. Budia, "Influence of azadirachtin and methoxyfenozide on life parameters of Spodoptera littoralis". J. Econ. Entomol., 2009, vol. 102, no. 4, pp. 1490-1496.

[136] E.A. Sammour; M.A. Kandit, and N.F. AbdelAziz, "The reproductive potential and fate of chlorfluazuron and lufenuron against cotton leafworm, Spodoptera littoralis (Boisd)". 
American-Eurasian J. Agric. Environ. Sci., 2008, vol. 4, no. 1, pp. 62-67.

[137] A. Kamaruzzaman, A. Reza, K. Mondal and S. Parween "Morphological abnormalities in Tribolium castaneum (Herbst) and Tribolium confusum Jacquelin du Val Duval due to cyromazine and pirimiphos-methyl treatments, alone or in combination". Invertebrate Survival Journal; 2006, no. 3, pp.97-102.

[138] G.A. Saryazdi, M.J. Hejazi and M. Saber, "Residual toxicity of abamectin, chlorpyrifos, cyromazine, indoxacarb and spinosad on Liriomyza trifolii (Burgess) (Diptera: Agromyzidae) in greenhouse conditions". Pestic. Phytomed. (Belgrade), 2012, vol. 27, no. 2, pp.107-116.

[139] F. Al-Mekhlafi, A.M. Mashaly, M.A. Wadaan and N.M. Al-Mallah, "Effect of different applicable conditions of the insect growth regulator (Cyromazine) on the southern cowpea weevils, Callosobruchus maculatus reared on peas". Pakistan J. Zool., 2012, vol. 44, no. 2, pp. 481-488.

[140] T.-X. Liu and T.-Y. Chen, "Effects of the insect growth regulator fenoxycarb on immature Chrysoperla rufilabris (Neuroptera: Chyrsopidae)". Fl. Entomol., 2001, vol. 84, no. 4, pp. 628-633.

[141] I.F.J. Saenz-de-Cabezon, V. Marco, F.G. Salmo and I. Perez-Moreno, "Effects of methoxyfenozide on Lobesia botrana Den and Schiff (Lepidoptera: Tortricidae) egg, larval and adult stages". Pest Management Science, 2005, no. 11, pp. 1133-1137.

[142] M. Mahmoudvand, H. Abbasipour, A. SheikhiGarjan and AR. Bandani "Decrease in pupation and adult emergence of Plutella xylostella (L.) treated with hexaflumuron". Chilean J. Agric. Res., 2012, vol. 72, no. 2, pp. 206-211.
[143] F. Budia, V. Marco and E. Viñuela, "Estudios preliminares de los efectos del insecticida $\mathrm{RH}-$ 5992 sobre larvas de distintas edades de Spodoptera exigua (Hübner)". Bol San Veg Plagas, 1994, no. 20, pp. 401-408

[144] A. Josephrajkumar, B. Subrahmanyam and S. Srinivasan, "Plumbagin and azadirachtin deplete haemolymph ecdysteroid levels and alter the activity profiles of two lysosomal enzymes in the fat body of Helicoverpa armigera (Lepidoptera: Noctuidae)". European Journal of Entomology, 1999, no. 96, pp. 347-353.

[145] N. Mitlin, G. Wiygul and J.W. Haynes, "Inhibition of DNA synthesis in boll weevil (Anthonomus grandis Boheman) sterilized by dimilin". Pestic., Biochem. Physiol., 1977, no. 7 pp. 559-563.

[146] R.T. Mayer, A.C. Chen and J.R. DeLoach, "Characterization of a chitin synthase from the stable fly, Stomoxys calcitrans L". Insect Biochem., 1980, no. 10, pp. 549-556.

[147] K. Tateishi, M. Kiuchi and S. Takeda "New cuticle formation and moult inhibition by RH5849 in the common cutworm, Spodoptera litura (Lepidoptera: Noctuidae)". App. Entomol. Zool., 1993, no. 28, pp. 177-184.

[148] M. Eizaguirre, C. López, Ch. Schafellner and F. Sehnal, "Effects of ecdysteroid agonist RH-2485 reveal interactions between ecdysteroids and juvenile hormones in the development of Sesamia nonagrioides". Arch. Insect Biochem. Physiol., 2007, no. vol. 65 , pp. $74-84$. 